\title{
INFLATION TARGETING IN EMERGING COUNTRIES: THE CASE OF BRAZIL*
}

\author{
Philip Arestis \\ University of Cambridge \\ Luiz Fernando de Paula \\ University of the State of Rio de Janeiro and CNPq \\ Fernando Ferrari-Filho \\ Federal University of Rio Grande do Sul and CNPq
}

\begin{abstract}
This paper is concerned with 'new' monetary policy, essentially what has come to be known as inflation targeting. While the paper aims to examine this policy in the case of emerging countries, the focus is on Brazil and the application of this monetary policy framework in the case of this country since 1999. The paper begins by discussing the theoretical foundations of inflation targeting, before it turns to an examination of the experience of inflation targeting in Brazil. The Brazilian experience is compared and contrasted with that of other similar countries. The paper concludes by suggesting that although inflation targeting may have had the intended impact, non-IT countries have also had a similar experience. Furthermore, the Brazilian experience with IT has been one of low growth and relatively high inflation.
\end{abstract}

Keywords: inflation targeting countries, non-inflation targeting countries, emerging country experience, Brazilian experience

\section{JEL Classification: E42; E52}

\section{Introduction}

The purpose of this paper is to examine Inflation Targeting (IT) in the case of emerging countries by concentrating essentially on the case of Brazil. IT is a new monetary policy regime (see, for example, Bernanke and Mishkin, 1997) that has been adopted by a significant number of countries (see, for example, Sterne, 2002). Brazil adopted this economic policy framework in June 1999. While the focus of this paper is on Brazil, we also examine the experience of other countries both for comparative purposes and for evidence of the extent of success of this 'new' economic policy by other IT countries. In addition, we compare the experience of Brazil with IT and with that of non-IT countries, and ask the question of whether it makes a difference in the fight against inflation whether a country has adopted IT or not.

We proceed as follows: section 2 deals with the more theoretical aspects of the IT framework. This is followed in section 3 by an examination of recent stabilization policies in Latin America, and Brazil in particular. This enables us to demonstrate how countries, and Brazil in particular, came to implementing IT strategies. Section 4 concentrates on the Brazilian experience with IT. Section 5 focuses on the nature of the Brazilian inflation and

\footnotetext{
${ }^{*}$ We are very grateful to Fabio Barcelos for generous research support in the form of collecting data on developing and emerging countries, especially on Brazil, and for producing the tables and figures for the paper. We are also grateful to Lilian Furquim for providing data relevant to Figure 5 (Appendix).
} 
compares the Brazilian IT experience with that of other 'similar' emerging countries. The latter group includes both countries within Latin America and other countries outside Latin America. A final section, section 6, summarizes and concludes.

\section{Theoretical aspects of IT}

There are a number of theoretical aspects that are the backbone of IT. We examine the following two aspects: main theoretical elements, and certain key operational aspects of IT. We begin with the first.

\subsection{Main theoretical elements}

This sub-section summarises the main theoretical elements of IT: there are six such elements as follows: ${ }^{1}$

(i) IT is a monetary policy framework whereby public announcement of official inflation targets, or target ranges, is undertaken along with explicit acknowledgement that price stability, meaning low and stable inflation, is monetary policy's primary long-term objective (King, 2002). The price stability goal may be accompanied by output stabilization so long as price stability is not violated. Explicit numerical target for inflation is published, either as a point or a range, and a time horizon for reaching the inflation target. Such a monetary policy framework, improves communication between the public, business and markets on the one hand, and policy-makers on the other hand, and provides discipline, accountability, transparency and flexibility in monetary policy. The focus is on price stability, along with three objectives: credibility (the framework should command trust); flexibility (the framework should allow monetary policy to react optimally to unanticipated shocks); and legitimacy (the framework should attract public and parliamentary support). In fact, credibility is recognised as paramount in the conduct of monetary policy to avoid problems associated with time-inconsistency (Barro and Gordon, 1983). It is argued that a policy, which lacks credibility because of time inconsistency, is neither optimal nor feasible (Kydland and Prescott, 1977; Calvo, 1978; Barro and Gordon, 1983).

(ii) A further role of IT is to 'lock in' the gains from 'taming' inflation. Bernanke et al. (1999) are explicit on this issue, when they argue that "one of the main benefits of inflation targets is that they may help to 'lock in' earlier disinflationary gains particularly in the face of one-time inflationary shocks" (p. 288). In an important contribution, though, Johnson (2003) finds rather mixed results for this contention. Johnson (op. cit.) compares actual forecasts with predicted forecasts undertaken by professional forecasters for five consecutive 12-month periods after the announcement of inflation targets. The study isolates the additional effect of the announcement of inflation targets on the level of expected inflation in the case of Australia, Canada, New Zealand, Sweden and the UK. Immediate reduction in expected inflation is registered in New Zealand and Sweden with a smaller effect and slower impact in Australia and Canada; inflation targets do not appear to have a significant impact in the UK.

(iii) In this framework, monetary policy is taken as the main instrument of macroeconomic policy. Fiscal policy is no longer viewed as a powerful macroeconomic instrument (in any case it is hostage to the slow and uncertain legislative process); in this way, "monetary policy moves first and dominates, forcing fiscal policy to align with monetary policy" (Mishkin, 2000, p. 4). Monetary policy is a flexible instrument for achieving medium-term stabilisation objectives, in that it can be adjusted quickly in response to macroeconomic

\footnotetext{
${ }^{1}$ Arestis and Sawyer (2005) provide an extensive discussion of the IT theoretical framework.
} 
developments. Indeed, monetary policy is viewed as the most direct determinant of inflation, so much so that in the long run the inflation rate is the only macroeconomic variable that monetary policy can affect. Monetary policy cannot affect economic activity, for example output, employment etc., in the long run.

(iv) Monetary policy should not be operated by politicians but by experts (whether banks, economists or others) in the form of an 'independent' central bank. Politicians would be tempted to use monetary policy for short-term gain (lower unemployment) at the expense of long-term loss (higher inflation), the time-inconsistency problem (Kydland and Prescott, 1977). An 'independent' central bank would also have greater credibility in the financial markets and be seen to have a stronger commitment to low inflation than politicians do. There is also the question of instrument independence, when the monetary policy instrument is under the control of the independent central bank, and goal independence, when the independent central bank sets the goal of monetary policy (Debelle and Fischer, 1994; Fischer, 1994). It is argued that instrument independence is preferable to insulate the independent central bank from time-inconsistent policies. However, in terms of the goals of monetary policy, it is thought that an independent central bank should be goal dependent so that its long-run preferences coincide with society's preferences, i.e. elected government's (Bernanke et al., 1999).

(v) A mechanism for openness, transparency and accountability should be in place with respect to monetary policy formulation. Openness and transparency in the conduct of monetary policy improve credibility. IT central banks publish inflation reports that might include not only an outlook for inflation, but also output and other macroeconomic variables, along with an assessment of economic conditions. There is also some accountability mechanism: if the inflation target is not met, there should be specific steps in place for the central bank to follow; this may include publishing an explanation, or submitting a letter to the government explaining the reasons for missing the target and how to return to it. Furthermore, transparency reduces uncertainty about the central bank's preferences, which is expected to lead to lower expected rate of inflation.

(vi) In the case of inflation targeting in an open economy, exchange rate considerations are of crucial importance, and we highlight this aspect in the case of emerging countries, and Brazil in particular in what follows in this paper. They transmit both certain effects of changes in the policy instrument, interest rates, and various foreign shocks. Given this critical role of the exchange rate in the transmission process of monetary policy, excessive fluctuations in interest rates can produce excessive fluctuations in output by inducing significant changes in exchange rates. This may suggest exchange rate targeting. However, the experience of a number of developing countries, which pursued exchange rate targeting but experienced financial crises because their policies were not perceived as credible, is relevant to the argument. The adoption of IT, by contrast, may lead to a more stable currency since it signals a clear commitment to price stability in a freely floating exchange rate system. This, of course, does not mean that monitoring exchange rate developments should not be undertaken. Indeed, weighting them into decisions on setting monetary policy instruments is thought desirable. Such an approach is thought to make undesirable exchange rate fluctuations less likely, thereby promoting the objective of financial and price stability (Bernanke and Gertler, 1999). 


\subsection{Operational aspects}

In terms of the operational framework of IT, a number of issues suggest themselves. To begin with, there is the establishment of inflation targets. This is the setting of a point target or a band and choosing the time period over which the target is expected to be achieved. It is important to note that the target horizon (over which the central bank is expected to achieve its inflation target) cannot be shorter than the control horizon (over which the policy is expected to affect the target variable). Clearly, choosing a range as opposed to a point for the inflation target contains a great deal of flexibility, not only for output stabilization but also for accommodating large movements in the nominal exchange rate; this is a particularly thorny issue in the case of emerging countries, and Brazil in particular as shown below. In those cases where a range is chosen, there is the question of symmetrical/asymmetrical response with respect to the central target. Symmetrical behaviour purports to show equal concern for both inflation and deflation. Such an approach reduces the likelihood of output declines and deflation, and indicates that the central bank cares about output fluctuations; this helps to maintain support for its independence. An asymmetric approach to inflation targeting may be advantageous when high inflation rates threaten credibility. This is often the case for developing and emerging countries adopting inflation targeting. A greater weight on overshoots than undershoots in the loss function is suggested under these circumstances.

IT also requires the setting up of a model or methodology that can provide information on future inflation, an issue that relates to the necessity of forecasting inflation. There is also the key issue of how to measure inflation. A relevant question in this context is whether the chosen price index should reflect the prices of goods and services for current consumption only, or for both current and future consumption. In the latter case constructing such a price index is, of course, not feasible. Then there is the problem of noisy or erratic short-run movements in prices, which suggests that an adjusted or core (long-term) price index should be used. Such an index might exclude from the general or headline price index items such as food and energy prices, shocks to the exchange rate, indirect tax or regulated prices on the assumption that such changes are the result of temporary and self-correcting short-term shocks that contain very little information on long-term price movements. Another important excluded category of items relates to changes directly associated with the policy change. Items, which vary directly with the policy instrument, such as mortgage payments, may be excluded from the definition of the targeted price index. Such effects, however, may contain significant and protracted secondround effects. For example, a rise in indirect taxes that lowers inflation temporarily, can affect aggregate demand, which may lower prices in the long run, thereby implying important loss of information on future price developments.

There is still the question of the trade-off between reducing deviations of inflation from target, and preventing a high degree of output variability. This is particularly pertinent in the case of supply shocks that cause inflation to exceed the target and are associated at the same time with lower output. Monetary authorities have a serious dilemma in these circumstances: the quicker the disinflation, the shorter the period of actual inflation being above its target. But then the quicker disinflation is, the greater the potential output variability. Policy preferences is an important determinant of this trade-off in addition to the magnitude of the supply shock. Flexibility is required in this context, which, however, may conflict with credibility if agents interpret it as reluctance by the central bank to deflate. There is, thus, another trade-off in this case between credibility and flexibility (Garfinkel and Oh, 1993).

This discussion highlights another important operational aspect. This relates to the question of monetary rules. Central banks on the whole are assumed to follow one form or 
another of Taylor Rules (Taylor, 1993). In its original formulation this monetary rule took the ad hoc formulation as shown in equation (1):

(1) $\quad \mathrm{R}_{\mathrm{t}}=\mathrm{RR}^{*}+\mathrm{p}^{\mathrm{T}}+\mathrm{d}_{1} \mathrm{Y}_{\mathrm{t}}^{\mathrm{g}}+\mathrm{d}_{2}\left(\mathrm{p}_{\mathrm{t}-1}-\mathrm{p}^{\mathrm{T}}\right)$

where the symbols are as follows: $\mathrm{R}$ is the rate of interest used for monetary control purposes, $\mathrm{p}^{\mathrm{T}}$ is desired inflation in the original Taylor (op. cit.) formulation (in current parlance it is the inflation target set by the central bank), $\mathrm{Y}^{\mathrm{g}}$ is output gap (i.e. the difference between actual and potential output), and $p$ is actual inflation. Equations of the type depicted in (1) are what is called Taylor rules, since Taylor (1993) who showed that a simple equation of this form, with $\mathrm{d}_{1}=0.5$ and $\mathrm{d}_{2}=1.5$, captures surprisingly well the behaviour of the US federal-funds rate and the Federal Reserve System (Fed) monetary policy. The nominal rate is increased more than one-to-one with respect to any increase in inflation. This policy reaction ensures that the real rate of interest will act to lower inflation. Given inflation, the real rate of interest is also increased as a result of output-gap positive changes. Taylor rules, therefore, require monetary policy to act automatically to inflation and output. These Taylor-type rules have been criticized (for example, Svensson, 2003) in terms of the possibility of real indeterminacy: if the rise in the nominal rate of interest in response to a rise in expected inflation is not high enough, then the real rate of interest falls raising demand which fails to check inflation. Mutatis mutandis, an excessive rise in the nominal rate of interest in response to a rise in expected inflation would also cause indeterminacy. However, indeterminacy can be avoided if monetary authorities respond rather aggressively, that is with a coefficient above unity to expected inflation, but not overly higher than unity. This result has been demonstrated in the closed-economy case (Clarida, Gertler and Galí, 2000) as well as in the small open-economy case (De Fiore and Liu, 2002).

\section{The Brazilian Experience: from the exchange rate anchor to IT}

Stabilization policies in Brazil, and more generally in Latin American countries, in the 1990s were based on some form of exchange rate anchor. Liberalization of the trade, financial and capital accounts was thought paramount. The experience with those programmes showed that although they were successful in ending the history of chronic high inflation, they showed, nonetheless, that local currency appreciation as a result of favourable differentials between domestic and foreign prices, was causing balance of payments disequilibria. A new problem emerged, which was closely related to the endeavour to achieve and maintain balance of payments equilibria. That was the use of high interest rates by monetary authorities to attract foreign capital. The need to maintain high interest rates in order to attract foreign capital increased public internal debt (monetary authorities had to sterilize the inflow of foreign capital), which deteriorated economic performance and fiscal balances. Under those conditions in a global world where financial and productive capital are mobile, the successful application of an internal stabilization policy generated an endogenous process of deteriorating economic conditions. That, then, left Latin American countries vulnerable to speculative attacks on their currencies, and thus subjected them to currency crises (Kregel, 1999). The currency crises in Mexico (1994-95), in Brazil (1998-99, and 2002), and in Argentina (2001-02), are some good examples of this dynamic process. That unhappy experience of some Latin American countries with pegged exchange rate regimes, and the associated era of deep financial crises in the 1990s, led them to search for alternative nominal anchors. Since at the same time more or less several industrial countries adopted the IT as a new monetary policy framework, it became an alternative policy regime for countries in Latin America. In fact, IT was adopted by Chile in 1990, Mexico in 1999, Colombia in 1999, Brazil in 1999, and Peru in 2002. 
The Real Plan, in Brazil, was created on the same basis as the stabilization programmes applied all over Latin America over the period of late 1980s to late 1990s. That system was characterised by a fixed or crawling-peg exchange rate, in combination with a more open trade policy. The exchange rate was the price anchor utilized throughout that period. ${ }^{2}$ During the exchange rate anchor period, very high interest rates were targeted designed to attract short-term foreign capital for balance-of-payments purposes. The volume of those capital flows was many times greater than the volume required for the needs of the balance of payments, thus raising the level of foreign reserves and leading to a real appreciation of the exchange rate. ${ }^{3}$ That appreciation resulted in significant balance of trade deficit. The effect of that liberal economic policy arrangement aggravated Brazil's external fragility and, consequently, the country had three speculative attacks on its currency over the three-year period 1995 to 1998. Furthermore, the Brazilian economy, from the third quarter of 1998 to the first quarter of 1999, was characterized by macroeconomic instability, resulting in a sharp outflow of short-term capital. Thus, repeated financial crises in a very short period of time, i.e. the South East Asian crisis and the Russian crisis along with the international recession of 1997-1998, contributed to deteriorating the Brazilian economy. In fact, as a result of the effects of the Russian crisis in particular, Brazil was forced to abandon its crawling-peg exchange rate and adopted a floating exchange rate regime. The exchange rate depreciated as a result, thereby producing significant price pass-through effects with the inevitable adverse consequences on the inflation front.

Following the transition to a floating exchange rate, in January 1999, Brazil adopted an IT regime, in June 1999, to keep inflation under control. At the same time, the Central Bank of Brazil (BCB) raised the basic short-term interest rate to accommodate the currency depreciation shock. As a result, an appreciation to the exchange rate occurred very fast and inflation, despite the huge devaluation in the beginning of 1999, ended the year in single figures.

\section{The Brazilian experience with IT}

\subsection{The institutional dimension}

The Brazilian IT monetary policy regime is modelled on the basis of the British IT model. The National Monetary Council $(\mathrm{CMN})^{4}$ sets the inflation targets, which are proposed by the Minister of Finance. The BCB Monetary Policy Committee (COPOM) ${ }^{5}$

\footnotetext{
2 The Brazilian Real Plan differed from Argentina's Convertibility Plan in that it adopted a more flexible exchange rate anchor. At the launch of the Brazilian programme in July 1994, the government's commitment was to maintain an exchange rate ceiling of one-to-one parity with the dollar. Moreover, the relationship between changes in the monetary base and foreign reserve movements was not explicitly stated, allowing some discretionary leeway. After the Mexican crisis, the exchange rate policy was reviewed and in the context of a crawling exchange rate range, the nominal rate began to undergo gradual devaluation. In early 1999, however, after six months of speculative pressure, the real was devalued and, some days later, the Brazilian government adopted a floating exchange rate. Ferrari-Filho and Paula (2003) provide a comprehensive analysis of the origins and development of the Real Plan.

${ }^{3}$ During the pegged exchange rate period, July 1994 to January 1999, the basic interest rate (Selic) was raised and kept at high levels in order to avoid large outflow of reserves.

${ }^{4} \mathrm{CMN}$ has three members: the Minister of Finance, the Minister of Planning and the Governor of the BCB. Besides the inflation target, $\mathrm{CMN}$ is also responsible for the approval of the main norms related to monetary and exchange rate policy, and to the regulation of the financial system.

${ }^{5}$ COPOM was created on 20 June 1996, and was assigned the responsibility of setting the stance of monetary policy and the short-term interest rate. It is composed of the members of the BCB's Board of Directors.
} 
has to achieve the inflation target through the use of the short-term interest rate. In fact the $\mathrm{BCB}$ makes use of the Taylor rule as its reaction function. The relevant relationship is ${ }^{6}$ :

$$
\mathrm{R}_{\mathrm{t}}=\alpha_{1} \mathrm{p}_{\mathrm{t}-1}+\left(1-\alpha_{1}\right)\left[\alpha_{0}+\alpha_{2}\left(\mathrm{E}_{\mathrm{t}} \mathrm{P}_{\mathrm{t}+\mathrm{j}}-\mathrm{P}_{\mathrm{t}+\mathrm{j}}\right)\right]+\alpha_{3} \mathrm{Y}_{\mathrm{t}-1}^{\mathrm{g}}+\alpha_{4} \Delta \mathrm{e}_{\mathrm{t}-1}
$$

where $\mathrm{R}_{\mathrm{t}}$ is the 'Sistema Especial de Liquidação e Custodia' (Selic), i.e. the rate of interest set by the COPOM, $\mathrm{E}_{t} \mathrm{P}_{t+\mathrm{j}}$ is inflation expectations and $\mathrm{P}^{*}{ }_{t+\mathrm{j}}$ is the inflation target, both referring to some period in the future, ${ }^{7} \mathrm{Y}^{\mathrm{g}}$ is the output gap (obtained by the difference between the actual and the HP-filtered series), and $\Delta \mathrm{e}_{t-1}$ is the nominal exchange rate variation.

Therefore, the Brazilian Taylor rule relates the interest rate to deviations of expected inflation from the target, allowing also for some interest rate smoothing $\left(\mathrm{R}_{\mathrm{t}-1}\right)$ and reaction to the output gap as well as movements in the exchange rate. The Brazilian IT regime sets year-end inflation targets for the current and the following two years. Inflation targets are based on the headline inflation index, i.e. extensive national consumer price index (IPCA) ${ }^{8}$. A certain degree of flexibility is introduced through defining IT within a range, which has varied between 2.0 or 2.5 percentage points above and below the central point target. The other main reason for the introduction of this flexibility is that it helps the BCB to achieve its inflation target in view of the serious supply shocks to which the Brazilian economy is exposed.

The inflation target is fulfilled when yearly variation of the inflation index is inside the set range. If inflation breaches the target set by the $\mathrm{CMN}$, the Governor of the $\mathrm{BCB}$ is required to write an open letter to the Minister of Finance explaining the reasons the target was missed, as well as the measures proposed to bring it back to target, and the time period over which these measures are expected to take effect. The interest rate target set by the COPOM is the target for the Selic interest rate, the interest rate for overnight interbank loans, collateralised by those government bonds that are registered with and traded on the Selic. The Selic target is fixed for the period between its regular meetings. The Governor of the $\mathrm{BCB}$, though, has the right to alter the Selic interest rate target anytime between regular COPOM meetings (once per month). This is made possible by the COPOM, which has the right to introduce a monetary policy bias at its regular meetings, where the bias refers to easing or tightening of monetary policy outside meetings. The COPOM authorizes the Governor of the BCB to alter the Selic interest rate target in the direction of the bias at anytime between regular COPOM meetings. Eight days after each meeting, the Committee releases the minutes on the $\mathrm{BCB}$ website and to the press through the $\mathrm{BCB}$ press officer. The minutes provide a summary of the COPOM's discussion and decisions. At the end of each quarter (March, June, September, December), the COPOM publishes the BCB Inflation Report, which provides detailed information on economic conditions, as well as the COPOM's inflation forecasts upon which changes in the Selic interest rate are determined. The objective of this report is to inform the public and the market about the goals, design and implementation of monetary policy.

\footnotetext{
${ }^{6}$ Adapted from Minella et al (2003, p. 11).

${ }^{7}$ In order to have a single measurement of the deviation of inflation from the target, BCB has used a weighted average of current year and following year expected deviation of inflation from the target, where the weights are inversely proportional to the number of months remaining in the year.

${ }^{8}$ IPCA covers a sample of families with a multiple of up to 40 times the minimum wage, which is determined every year by the Brazilian federal government. It now stands at approximately US\$ 130 per month, and it is thought to be enough to cover the basic needs of a family. The sample covered by IPCA has a broad geographical basis that includes families in the biggest cities of Brazil. IPCA is calculated by IBGE (National Bureau of Geography and Statistics).
} 


\subsection{Brazil's experience with IT}

Table 1 shows actual inflation and the targets for 1999-2005. From 1999 (when IT was introduced in Brazil) ${ }^{9}$ to 2002, the tolerance intervals were 2 percentage points above and below the central target; for 2003 and 2004 the intervals were enlarged to 2.5 percentage points. The inflation rate was $8.9 \%$ and $6.0 \%$ for targets of $8 \%$ and $6 \%$ in 1999 and 2000, respectively. The targets were within the acceptable range. However, in 2001 and 2002, several external and domestic shocks - such as domestic energy crisis in Brazil, effects of $11^{\text {th }}$ September 2001, the Argentine crisis, and the confidence crisis related to the presidential election in 2002 - hit the Brazilian economy with significant impacts on inflation. Indeed, the inflation rate reached $7.7 \%$ in $2001,1.7 \%$ above the target's upper range, and $12.5 \%$ in 2005 , more than 5 percentage points above the upper range. According to Minella et al. (2003, p.6-8), the exchange rate rose $20.3 \%$ and $53.5 \%$ in 2001 and 2002, respectively. As a result, in 2001, 38\% of the inflation rate can be explained by the exchange rate depreciation, whereas for 2002 the contribution of the exchange rate stood at $46 \% .{ }^{10}$ In 2003 the inflation rate was $9.3 \%$ above the adjusted target of $4.5 \%$, and outside the range of $2.5 \%$ tolerance interval. ${ }^{11}$ The high inflation in 2003 was due mainly to the initial effect of 2002 high inflation, in spite of the maintenance of the conservative economic policy with very high interest rates by the new President, Lula da Silva, from the Workers Party. In 2004 IPCA was $7.6 \%$, only slightly less than the upper range of the inflation target $(8.0 \%)$. Growth in administered prices (mainly gasoline, health plans, fixed telephone and electricity rates) in the same year, reached $10.2 \%$, accounting for $29.0 \%$ of the change in the IPCA or equivalently $2.94 \%$ out of $10.2 \%$. Finally, in 2005 the inflation rate was $5.7 \%$, which was within the upper and lower tolerance levels for inflation set by the $\mathrm{CMN}$ for that year. The factors that influenced the lower growth rate in prices (mainly in market prices) in 2005 were, among others, an abundant supply of farm products (rice, perishable foodstuffs and soy bean) and, especially, exchange appreciation.

Table 1 here

Examining Table 1 more closely, further comments are in order. It is notable that over the period 1999-2005 IT targets in Brazil were within the set range in 4 out of the 7 years of the operation of this monetary policy strategy. The targets were missed in 2001, 2002 and 2003 (despite raising the inflation target to $5.5 \%$ from $3.75 \%$ ) by a substantial margin, especially in 2002. On a different occasion (2004), the inflation target was only met after it had been raised by mid-2003 (see footnote 11). It may, thus, be concluded that IT in Brazil was not completely unsuccessful over the first seven years of its implementation. This begs the question of comparing Brazil's IT performance with that of other emerging countries both within Latin America and outside it, and also both with IT and non-IT countries. Section 5 is designed to conduct this exercise, and we turn our attention to it next.

\section{Comparing the Brazilian experience with other 'similar' countries}

\footnotetext{
${ }^{9}$ For more information on the macroeconomic background that led to the shift of IT in Brazil, see Bogdanki et al. (2000).

${ }^{10}$ Minella et al. (2003) calculations are based on the structural model of the BCB and the information concerning the mechanisms for the adjustment of administered prices.

${ }^{11}$ CMN Resolution number 2972, 27 June 2002, changed the inflation targets for 2003, while later Resolution number 3108, 25 June 2003, changed inflation targets for 2004. They were raised to $4.0 \%$ and 5.5\% for 2003 and 2004, from the original inflation targets of $3.25 \%$ and $3.75 \%$, respectively.
} 


\subsection{Inflation and GDP performance in emerging countries}

This exercise is undertaken with the help of Tables 2-4, which contain data that concern inflation and GDP (average, standard deviation and coefficient of variation) of a group of emerging countries that have adopted IT and those that have not adopted IT. ${ }^{12}$ Two groups of emerging countries are reported: the biggest Latin American countries and some other emerging countries. Long periods of high inflation (inflation above $50 \%$ per year) in the data have not been included, as for example in the case of Brazil before 1995 and Israel before $1986 .{ }^{13}$

Inspection of Tables 2-4 clearly shows that the fall of inflation is a recent general tendency in emerging countries, whether or not they adopt an IT regime. Although in all IT emerging countries the rate of inflation declined after the adoption of IT, in most of them the coefficient of variation increased (Table 2). It is also true that countries that did not adopt IT experienced improvements around the same time as IT countries (Tables 3-4). Indeed, some emerging non-IT countries, such as China, India, Egypt and Malaysia, have had inflation rates below 4 percent per year in the last few years. For some countries, China, India and Malaysia, the stability of the nominal exchange rate has had an important role for price stabilization purposes. So, IT and non-IT countries have experienced similar reductions in inflation in recent years. ${ }^{14}$ Theory suggests that 'flexible' IT stabilizes both inflation and output. However, there is no clear evidence that emerging countries that adopt IT have had a better performance in GDP terms (both in terms of output growth and GDP coefficient of variation) when compared to the emerging countries that do not adopt IT reported in this paper. Indeed, China, India and Malaysia are among the countries that have had the highest output growth in recent years, and they are non-IT countries (their growth rates are $9.8 \%, 6.1 \%$ and $6.0 \%$, respectively, in the years 1992-2003). Consequently, there is no evidence that inflation targeting improves performance in emerging economies as measured by the behaviour of inflation and output. This finding suggests that better performance resulted from something other than IT. ${ }^{15}$

\section{Tables 2-4 here}

The picture in Latin American countries should be interpreted with attention given that these countries have suffered currency crises recently: Mexico in 1994-95, Brazil in 1998-99 and 2002, and Argentina in 2001-2002. Such crises have had big effects on both

\footnotetext{
${ }^{12}$ For most countries that do not adopt IT we use data from 1992 to 2003 . Since South Africa adopted IT very recently (2002), we have included this country in the group of non-IT, but using data only until 2001.

${ }^{13}$ The reason for excluding periods of high inflation is that during those periods the rate of inflation is so high and after the price stabilization (in general with some sort of exchange rate anchor) the rate of inflation is so low (compared to the former period), that the shift produces a huge distortion in the time series of inflation figures. This would complicate the comparison between the period before IT and after IT in Table 2. For Table 3 and Table 4, however, we have not excluded any data, unless they were not available.

${ }^{14}$ Note that in our sample (Tables 2-4), Venezuela is the single exception, as average inflation increased from 1980-1991 (35.4\%) to 1992-2003 (40.2\%), although since 1996 the inflation rate in this country has traced a downward trend.

${ }^{15}$ One might argue that these findings are due to specific economic problems of emerging countries, in a way that developed countries are not faced with, and thus IT might be better suited for these countries. However, a recent paper on OECD countries shows that this is not the case: comparing seven OECD countries that adopted inflation targeting in the early 1990s to thirteen that did not, Ball and Sheridan (2003) find that on average there is no evidence that IT improves performance as measured by the behaviour of inflation, output, and interest rates. They conclude that "the formal and institutional aspects of targeting - the public announcements of targets, the inflation reports, the enhanced independence of central banks - are not important. Nothing in the data suggests that convert targets would benefit from adopting explicit targets" ( $\mathrm{p}$. 29, italics added; see also Arestis and Sawyer, 2005).
} 
inflation and GDP in these countries. Argentina, after the experience of hyperinflation (1989-1990), adopted a currency board in 1991 and the inflation rate declined sharply during the 1990s. In 2002 the country had a serious currency crisis and, as result, a sharp recession in 2001-2002 took place, followed by a rapid recovery after the crisis. Mexico has had poor economic performance with a declining inflation after the 1994 "Tequila" crisis. Although general conclusions are difficult to derive in the case of Latin America in view of the fact that IT is a recent import in these countries, a general observation emerges from this experience: in three cases, Brazil, Colombia and Mexico, economic performance worsened since the adoption of IT by these countries (Tables 2-4). Chile is an exception. It is the single Latin American country that has had real GDP growth above 5\% on average. Non-IT countries have had similar experiences (Table 3 ).

\subsection{Inflation and GDP performance in Brazil}

Although there is a clear downward trend in inflation in emerging countries, Brazil is an interesting case. Inflation has been maintained high in relation to other IT countries over the relevant period; but, then, the coefficient of variation is the lowest over the same period (Table 2). Furthermore, Brazil's GDP performance has been poor. When we consider the period of IT implementation (1999 to today), the average growth rate of GDP is only $2.3 \%$. In addition, GDP has followed a stop-go pattern over this period: according to BCB data, GDP growth was $0.8 \%$ in $1999,4.4 \%$ in $2000,1.3 \%$ in $2001,1.9 \%$ in 2002 , $0.5 \%$ in $2003,4.9 \%$ in 2004 and $2.3 \%$ in 2005 .

During the IT regime, the interest rate has been very high in Brazil. The average nominal basic interest rate (Selic) was $19.67 \%$ over the period 1999 to 2005 (Figure 1) while the average real interest rate (Selic/IPCA) during this period was $10.57 \%$. It was so high because monetary policy aimed at keeping inflation under control, reducing public debt, and stabilizing the exchange rate volatility. Indeed, empirical studies show that monetary authorities use interest rate not only to control inflation directly but also to influence the exchange rate, trying to control exchange rate pressures, with an evident 'fear of floating'. ${ }^{16}$ The consequences of high interest rates are: (i) serious constraint on economic growth, through the price of credit (loan rates) and entrepreneurs' poor expectations; and (ii) it increases public debt, which is formed mainly by indexed bonds or short-term pre-fixed bonds. ${ }^{17}$ Despite the significant improvement in the balance of payment figures since 2003, due essentially to the surplus in the trade balance increasing, Brazil's recent experience shows that in countries with a high level of external debt and a fully-liberalized capital account, external capital flows can cause periods of intense exchange rate instability. ${ }^{18}$ This can jeopardize efforts to achieve and maintain announced inflation targets. This situation has also caused low economic growth, because monetary authorities tend to increase interest rates during periods of external turbulence in order to meet inflation targets, and also stabilize exchange rates.

Figure 1 here

\footnotetext{
${ }^{16}$ Mendonça (2005), using a Taylor rule to study the determination of interest rate by the $\mathrm{BCB}$, over the period 1999-2004, finds that exchange rate changes explained a great deal of the variation of the Selic interest rate (around 57\% after one year of the exchange rate shock in 2003).

${ }^{17}$ The behaviour of the domestic public debt in Brazil has proved particularly vulnerable to changes in the rate of interest and exchange rate (see, in this regard, Paula and Alves Jr., 2003).

${ }^{18}$ According to data from BCB, the ratio of external debt to exports declined from 3.6 in 2001 to 2.1 in 2004 , due to the recent increase in exports, and the ratio of foreign reserves to external debt increased from 17.1 in 2001 to 26.3 in 2004. Although there is a significant improvement recently in the external vulnerability indicators, they are still in the range of what is considered 'danger' for the country.
} 
In Brazil, exchange rate volatility has been considerable (Figure 2). As argued earlier, macroeconomic instability brought a strong currency devaluation of the Real (the Brazilian currency), which, as a result, affected domestic prices via the exchange rate passthrough. This came about through the direct impact of devaluation on the imported inputs or indirectly through the 'monitored' prices. Monitored or administered prices are defined as those that are relatively insensitive to domestic demand and supply conditions or that are in some way regulated by a public agency. The group includes oil by-products, telephone fees, residential electricity, and public transportation. Its dynamics differ from those of market prices in three ways: "i) dependence on international prices in the case of oil byproducts; ii) greater pass-through from the exchange rate; ${ }^{19}$ and iii) stronger backwardlooking behavior" (Minella et al., 2003, p. 7), as electricity and telephones rates are generally adjusted annually by the General Price Index (IGP) ${ }^{20}$. Our estimation of the percentage of monitored prices to IPCA is around 28\% on average from April 2003 to December 2005 (Figure 3). Furthermore, Figure 4 shows that administered prices have increased more than market prices. Indeed, while the accumulated inflation rate related to market prices was $57.0 \%$ from 1999 to 2005 , the administered price rate was $137.0 \%$, that is it increased by more than $50.0 \%$ in relation to the former. ${ }^{21}$ Administered prices in Brazil are set by contracts based on past variation of the price index. It is for this reason that some degree of persistence is evident in the formation of this particular price index.

Figures 2-4 here

A final comment on the transmission channel from exchange rate to inflation in Brazil, is in order. Exchange rate variations affect the IGP, which in its turn affects the index of administered prices. As administered prices change ${ }^{22}$, IPCA is also affected. IPCA is also affected directly by exchange rate changes due to their effects on the imported inputs. Since IGP has been higher than IPCA, the latter has been influenced by the IGP behaviour through administered price adjustments (Figure 5). ${ }^{23}$ On the other hand, periods of appreciation of the exchange rate have resulted in a decrease in the rate of inflation, after a time lag. As we show in section 4.2, the decline of the inflation rate in 2005, compared to 2003 and 2004, is basically related to the exchange rate appreciation over the period. So,

\footnotetext{
${ }^{19}$ According to Minella et al. (2003, p.7) "[t]here are three basic links: i) the price of oil by-products for consumption depends on international oil prices denominated in domestic currency; ii) part of the resetting of electricity rates is linked to changes in the exchange rate; and iii) the contracts for price adjustments for electricity and telephone rates link these adjustments, at least partially, to the General Price Index (IGP), which is more affected by the exchange rate than the consumer price indexes".

${ }^{20}$ IGP is prepared by Getulio Vargas Foundation, a private foundation, and it is calculated through a weighted index that includes wholesale price index $(60.0 \%)$, consumer price index $(30.0 \%)$ and national index of building costs $(10.0 \%)$. The reason for the use of this index to adjust electricity and telephones rates (instead of IPCA) is that when these services were privatised in the second half of the 1990s, Brazilian government was interested to attract foreign firms, and for these firms IGP is better than IPCA, as it is much more sensitive to exchange rate variations (due to the high weight of the wholesale price on it).

${ }^{21}$ The synthetic IPCA, which includes both market and monitored prices, from 1999 to 2005 , was $73.9 \%$, according to own calculations.

${ }^{22}$ Minella et al. (2003, p. 25) estimated that the pass-through to administered prices from July 1997 until December 2002 was $25 \%$, resulting in a pass-through of about $16 \%$ for the headline IPCA.

${ }^{23}$ Figueiredo and Ferreira (2002), using a simple regression, identify the general index of prices and the index of domestic supply prices as the main components that explain the difference between movements in markets prices and administered prices.
} 
inflation in Brazil is very much influenced by exchange rate movements. ${ }^{24}$ Under these conditions, monetary policy may have some effect on market-determined prices, but it is not very effective in controlling administered prices. Consequently, in view of the importance of administered prices in the determination of the Brazilian inflation rate, inflation pressures result in the BCB having to increase interest rates higher than might be necessary to restrain inflation that derives from market prices. This is so since the BCB has to account for the secondary effects that emanate from the shocks of monitored prices. ${ }^{25}$

Furthermore, Brazil is the only country in the world where the central bank determines directly the interest rate that remunerates public debt and uses the same rate as the operational target for the reserves of the banking sector. This anomalous situation is a heritage of the high inflation era that still remains intact nowadays. Indeed, as more than $50.0 \%$ of federal securities are indexed to the overnight rate (Selic) and they are used by the banks to back fixed income funds (short-term funds that are very popular in Brazil), any increase in the interest rate results in an immediate increase in the total stock of public debt. ${ }^{26}$ It follows that under such circumstances, a rise in the interest rate (Selic) by BCB, as the case has been since mid-2004, is followed, ceteris paribus, by an increase in the liquidity conditions of the economy as measured by broad monetary aggregates. It can also cause a higher level of consumption expenditures by firms and households, as the increase in the remuneration of the fixed income funds results in a positive wealth effect in consumption. This increase in expenditure outweighs the negative impact on consumption as a result of the higher rate of interest (Nakano, 2005). There are two consequences of this modus operandi of monetary policy in Brazil. First, in order to have some effect over demand, BCB needs to increase the rate of interest sufficiently high so that banks are forced to ration credit due to the increased default risk. Second, the increase in the rate of interest, due to the arbitrage between domestic and foreign interest rates, causes an appreciation of the exchange rate. This works as a positive shock on the supply-side of the economy, since it reduces the cost of imported raw materials and the price of the tradable goods in the domestic market. Consequently, it is mainly through the exchange rate channel that monetary policy is most effective in countries like Brazil.

Summing up, inflation in Brazil has been mainly cost-determined, explained by negative or positive supply shocks (movements in the exchange rate, changes in the international prices of commodities and energy, among others) and by partial inertia due to the indexation of the administered prices.

Figure 5 here

\footnotetext{
${ }^{24}$ Ferreira (2004), using a VAR model to evaluate the determinants of the rate of inflation in Brazil in 19952004, finds a positive response of inflation to shocks in nominal exchange rate, an effect that spreads over time. In the same connection, Gomes and Aidar (2005) estimate, using a VAR, a Taylor rule for the Brazilian economy from January 1999 to May 2004, and conclude that $24.4 \%$ of the inflation rate (IPCA) variation is explained by the exchange rate. It is interesting that some economists of the $\mathrm{BCB}$ also conclude that "exchange rate volatility is an important source of inflation variability. The design of the inflation-targeting framework has to take into account this issue to avoid that a possible non-fulfilment of inflation targets as a result of exchange rate volatility may reduce the credibility of the central bank" (Minella et al., 2003, p. 29).

${ }^{25}$ The credit channel is also limited in Brazil since the ratio of credit to GDP has been around 24-30\% in 2000-04, according to data from BCB, while it was $45.3 \%$ in US, $84.7 \%$ in Japan and $103.7 \%$ in the euro area in 2000 (Belaisch, 2003).

${ }^{26}$ According to data from IPEADATA, the ratio net public debt-over-GDP increased from $34.4 \%$ in 1997 to $52.6 \%$ in 2001 , and since then it has been more than $50.0 \%$.
} 


\section{Summary and Conclusions}

We have summarized the theoretical aspects of IT, and the principles that govern its implementation in the case of Brazil. It is clear from this analysis that the authorities in Brazil adhere religiously to the theoretical principles of the IT framework. We have examined the experience of Brazil with IT, compared it with the experience of the pre-IT period and with the experience of other countries, IT and non-IT ones.

Two general conclusions emerge from this analysis. IT countries appear to have been successful in taming inflation. But, then, so have non-IT countries. Furthermore, although Brazil has implemented IT as the theory of the framework suggests, inflation rates over the IT period have been high. Brazil has one of the highest interest rates in the world, along with inflation, which has been maintained at a significantly high level. The BCB has to maintain very high interest rates in its attempt to control inflation. High interest rates have caused poor economic growth performance, and deterioration of other macroeconomic variables, such as public debt. It appears that we have a rather bad economic scenario in Brazil: low economic growth with relatively high inflation.

Our results conform to recent contributions on the IT experience of a number of Latin American countries. Especially so with Eichengreen (2002) contention that IT is more complicated in countries like the Latin American ones, essentially for three main reasons: their economies are exposed to financial and international commodity shocks because of the liberalization of the balance of payments trade, financial and capital accounts; their liabilities are almost dollarized; and their policy makers lack credibility. The first and the second reasons are particularly pertinent in the case of Latin America countries. Openness exposes these economies to disturbances that emanate from exchange rate fluctuations that cause pass-through inflation. Liability dollarization affects financial institutions, because in general terms the banking system of Latin America countries is weak, and as such it brings financial vulnerability when external shocks occur. However, Paula and Alves Jr. (2003) demonstrate that this is not typical of the Brazilian banking sector in recent years. Moreover, IT is too rigid for these countries essentially because it affects economic growth and exchange rate flexibility that is required under such a regime of monetary rules. The latter can cause financial instability, a very real possibility in these countries as history has demonstrated vividly. Schmidt-Hebel and Werner (2002) are very clear on the dangers of IT: "all Latin American inflation targeters are open economies that employ floating exchange rate regimes ... [and] are subject to large external shocks and significant exchange rate volatility, and the exchange rate may therefore play an important role in the conduct of monetary policy under inflation targeting" (p. 2). Exchange rate market volatility generates frequent changes to inflation rates and results in countries not being able to meet their inflation targets.

The larger external shocks faced by Latin America countries affect the exchange rate, and, consequently, the inflation rate, leading to higher interest rates to curb the inflationary pressures. As a result, these economies in general are confronted by higher volatility of interest rates and exchange rates. In this context, "monetary policy in emerging economies may therefore be more sensitive to exchange rate movements both indirectly (because of pass-through effects on inflation) and directly (because the exchange rate is an additional argument in central bank objective functions, reflecting their concern for devaluation-induced bank failures and domestic recessions)" (Schmidt-Hebel and Werner, op.cit., p. 15). In other words, the pass-through from exchange rate changes to inflation is larger and more significant in the Latin American economies than in industrial countries because the former have a substantially higher degree of openness, a history of high inflation, and low central bank credibility. In addition, Latin American countries present large mismatches between foreign currency assets and liabilities, which bring two adverse 
shocks: self-fulfilling attacks and financial crises on the country's asset and domestic recession following large exchange rate depreciations. It is the case that Latin American countries are susceptible to supply shocks, perhaps more so than many other countries, than to demand shocks. To the extent that this is validated, IT might not work as effectively as in those countries where demand shocks dominate over supply shocks.

\section{References}

Arestis, P. and Sawyer, M. (2005), "Inflation Targeting: A Critical Appraisal”, Greek Economic Review, (Forthcoming).

Ball, L. and Sheridan, N. (2003), "Does Inflation Targeting Matter?", NBER Working Paper Series, 9577, 1-47.

Belaisch, A. (2003). “Do Brazilian Banks Compete?”. IMF Working Paper WP/03/113, Washington.

Bernanke, B.S. and Gertler, M. (1999), "Monetary Policy and Asset Price Volatility", in New Challenges for Monetary Policy, Proceedings of the Symposium Sponsored by the Federal Reserve Bank of Kansas City, Jackson Hole, Wyoming, August 26-28.

Bernanke, B.S., Gertler, M. and Gilchrist, S. (1999), "The Financial Accelerator in a Quantitative Business Cycle Framework", in J. Taylor and M. Woodford (eds.), Handbook of Macroeconomics, Volume 1, Amsterdam: North Holland.

Barro, R.J. and Gordon, D.B. (1983), "A Positive Theory of Monetary Policy in a Natural Rate Model", Journal of Political Economy, 91(3), 589-619.

Bernanke, B.S. and Mishkin, F.S. (1997), "Inflation Targeting: A New Framework for Monetary Policy?", Journal of Economic Perspectives, 11(2), 97-116.

Bogdanski, J., Tombini, A.A. and Werlang, S.R. (2000), "Implementing Inflation Targeting in Brazil”, Working Papers Series, Banco Central do Brasil, July, 1-29.

Calvo, G. (1978), "On the Time Consistency of Optimal Policy in the Monetary Economy", Econometrica, 46(4), 1411-1428.

Clarida, R., Gali, J. and Gertler, M. (2000), "Monetary Policy Rules and Macroeconomic Stability: Evidence and Some Theory", Quarterly Journal of Economics, 115(1), 147-180.

Debelle, G. and Fischer, S. (1994), "How Independent Should a Central Bank Be?”, in J.C. Fuhrer (ed.), Goals, Guidelines, and Constraints Facing Monetary Policymakers, 195-221, Boston: Federal Reserve Bank of Boston.

De Fiore, F. and Liu, Z. (2002), "Openness and Equilibrium Determinacy Under Interest Rate Rules", European Central Bank Working Paper No. 173, Frankfurt: European Central Bank.

Eichengreen, B. (2002), “Can Emerging Markets Float? Should they Inflation Target?", Working Papers Series, Banco Central do Brasil, February, 1-46.

Ferrari-Filho, F. and Paula, L.F. (2003). "The Legacy of the Real Plan and an Alternative Agenda for the Brazilian Economy", Investigación Económica, 244, 57-92.

Ferreira, A.B. (2004). "Metas para a Inflação e Vulnerabilidade Externa: um Estudo do Brasil". Master Dissertation. Belo Horizonte, CEDEPLAR/UFMG.

Figueiredo, F.M. and Ferreira, T.P. (2002). "Os Preços Administrados e a Inflação no Brasil”. Working Papers Series, Banco Central do Brasil, December, 1-32.

Fischer, S. (1994), "Modern Central Banking", in F. Capie, C.A.E. Goodhart, S. Fischer and N. Schnadt (eds.), The Future of Central Banking, 262-308, Cambridge: Cambridge University Press. 
Garfinkel, M.R. and Oh, S. (1993), "Strategic Discipline in Monetary Policy with Private Information: Optimal Targeting Horizons", American Economic Review, 83(1), 99117.

Gomes, C. and Aidar, O. (2005). "Metas Inflacionárias, Preços Livres e Administrados no Brasil", Proceedings of X Encontro Nacional de Economia Política, SEP, Campinas/Brazil.

International Monetary Fund (IMF) (2002), International Financial Statistics Yearbook, Washington, IMF.

International Monetary Fund (IMF) (2004), International Financial Statistics Yearbook, Washington, IMF.

Johnson, D.R. (2003), "The Effect of Inflation Targets on the Level of Expected Inflation in Five Countries", Review of Economics and Statistics, 85(4), 1076-1081.

King, M. (2002), "The Inflation Target Ten Years On”, Bank of England Quarterly Bulletin, Summer, 42(4), 459-474.

Kregel, J. (1999), "Was there an Alternative to the Brazilian Crisis?", Revista de Economia Política, 19(3), 23-38.

Kydland, F. and Prescott, E.C. (1977), "Rules Rather than Discretion: The Inconsistency of Optimal Plans", Journal of Political Economy, 85(3), 473-492.

Mendonça, H. (2005). "O Efeito dos Preços Administrados na Taxa de Juros Brasileira", Proceedings of X Encontro Nacional de Economia Politica, SEP, Campinas/Brazil.

Minella, A., Freitas, P., Goldfajn, I. and Muinhos, M. (2003), "Inflation Targeting in Brazil: Constructing Credibility under Exchange Rate Volatility". Working Papers Series, 77, Banco Central do Brasil, November, 1-32.

Mishkin, F.S. (2000), "What Should Central Banks Do?", Federal Reserve Bank of St. Louis Review, 82(6), 1-13.

Nakano, Y. (2005). "O Regime Monetário e de Dívida Pública Brasileira e a Alta Taxa de Juros". Revista de Conjuntura Econômica, 59 (11), 10-12.

Paula, L.F. and Alves, Jr., A.J. (2003), "Banking Behaviour and the Brazilian Economy After the Real Plan: a Post-Keynesian Approach", BNL Quarterly Review no. 227, 337-365.

Schmidt-Hebel, K. and Werner, A. (2002), "Inflation Targeting in Brazil, Chile, and Mexico: Performance, Credibility, and the Exchange Rate", Banco Central de Chile, Documentos de Trabajo, No. 171.

Sterne, G. (2002), "Inflation Targets in a Global Context", in N. Loayza and R. Soto (eds.), Inflation Targeting: Design, Performance, Challenges, Central Bank of Chile: Chile.

Svensson, L.E.O. (2004), "Commentary on Meyer: Practical Problems and Obstacles to Inflation Targeting", Federal Reserve Bank of St. Louis Review, 86(4), 161-164.

Taylor, J.B. (1993), "Discretion Versus Policy Rules in Practice", Carnegie-Rochester Conference Series on Public Policy, December, 195-214. 


\section{TABLES AND FIGURES}

Table 1. Brazil - inflation targets and headline consumer price index (IPCA)

\begin{tabular}{c|c|c|c}
\hline Year & $\begin{array}{c}\text { Inflation } \\
\text { target }\end{array}$ & $\begin{array}{c}\text { Tolerance } \\
\text { intervals +/- }\end{array}$ & IPCA \\
\hline \hline 1999 & $8.0 \%$ & $2.0 \%$ & $8.94 \%$ \\
2000 & $6.0 \%$ & $2.0 \%$ & $5.97 \%$ \\
2001 & $4.0 \%$ & $2.0 \%$ & $7.67 \%$ \\
2002 & $3.5 \%$ & $2.0 \%$ & $12.53 \%$ \\
2003 & $4.0 \%^{*}$ & $2.5 \%$ & $9.30 \%$ \\
2004 & $5.5 \%^{*}$ & $2.5 \%$ & $7.60 \%$ \\
2005 & $4.5 \%$ & $2.5 \%$ & $5.69 \%$ \\
\hline
\end{tabular}

Source: Central Bank of Brazil (2006), www.bcb.gov.br (data obtained in May).

$\left({ }^{*}\right)$ The original inflation target was $3.25 \%$ (tolerance interval of $2.0 \%$ ) in 2003 and $3.75 \%$ (tolerance interval of 2.5\%) in 2004 (see footnote 11 above).

Table 2. Emerging IT countries

\begin{tabular}{|c|c|c|c|c|c|c|c|c|c|c|c|c|}
\hline \multirow{3}{*}{ Country } & \multicolumn{6}{|c|}{ Before IT } & \multicolumn{6}{|c|}{ After IT } \\
\hline & \multicolumn{3}{|c|}{ Inflation } & \multicolumn{3}{|c|}{ GDP } & \multicolumn{3}{|c|}{ Inflation } & \multicolumn{3}{|c|}{ GDP } \\
\hline & Average & SD & $\mathrm{CV}$ & Average & SD & $\mathrm{CV}$ & Average & SD & $\mathrm{CV}$ & Average & SD & $\mathrm{CV}$ \\
\hline \multicolumn{13}{|l|}{$\begin{array}{l}\text { Latin American } \\
\text { countries }\end{array}$} \\
\hline Brazil & 9.71 & 9.06 & 0.93 & 2.58 & 1.76 & 0.68 & 8.88 & 2.42 & 0.27 & 1.78 & 1.56 & 0.88 \\
\hline Chile & 20.45 & 5.94 & 0.29 & 4.50 & 2.99 & 0.66 & 8.01 & 5.83 & 0.73 & 5.64 & 3.56 & 0.63 \\
\hline Colombia & 23.71 & 4.26 & 0.18 & 3.62 & 1.64 & 0.45 & 6.80 & 2.21 & 0.32 & 1.86 & 1.76 & 0.95 \\
\hline Mexico & 20.76 & 9.37 & 0.45 & 3.43 & 3.60 & 1.05 & 8.41 & 4.97 & 0.59 & 2.36 & 2.77 & 1.17 \\
\hline \multicolumn{13}{|l|}{$\begin{array}{l}\text { Other emerging } \\
\text { countries }\end{array}$} \\
\hline Israel & 23.43 & 12.18 & 0.52 & 4.43 & 12.18 & 0.52 & 7.07 & 4.43 & 0.63 & 3.86 & 2.99 & 0.77 \\
\hline Poland & 29.74 & 11.16 & 0.38 & 5.23 & 1.74 & 0.33 & 6.21 & 4.39 & 0.71 & 5.18 & 5.41 & 1.04 \\
\hline Czech Republic & 13.73 & 16.43 & 1.20 & n.a. & n.a. & n.a. & 3.88 & 3.69 & 0.95 & 1.80 & 1.72 & 0.95 \\
\hline Thailand & 4.97 & 2.06 & 0.41 & 5.28 & 6.56 & 1.24 & 1.41 & 0.55 & 0.39 & 4.75 & 2.25 & 0.47 \\
\hline South Korea & 6.18 & 1.71 & 0.28 & 7.46 & 1.98 & 0.27 & 3.49 & 2.28 & 0.65 & 4.17 & 5.98 & 1.44 \\
\hline
\end{tabular}

$\mathrm{SD}=$ Standard deviation; $\mathrm{CV}=$ coefficient of variation (SD/average)

Source: IMF (2002, 2004) / IPEADATA for Brazil's inflation / Polish Market Review, August 2003.

Note: Before IT / After IT : Brazil: 1995-1998/1999-2003 ; Colombia; 1989-1998/1999-2003 ; Mexico;1989-1998/1999-2003;

Chile:1981-1990/1991-2003;Czech Republic:1988-1997/1998-2003 (until 1992, data from Czechoslovakia);

Israel: 1986-1991/1992-2003; Poland:1992-1997/1998-2003; Thailand:1990-1999/2000-2003; South Korea:1988-1997/1998-2003. 
Table 3. Emerging non-IT countries

\begin{tabular}{|c|c|c|c|c|c|c|c|c|c|c|c|c|}
\hline \multirow{3}{*}{ Country } & \multicolumn{6}{|c|}{ 1980-1991 } & \multicolumn{6}{|c|}{ 1992-2003 } \\
\hline & \multicolumn{3}{|c|}{ Inflation } & \multicolumn{3}{|c|}{ GDP } & \multicolumn{3}{|c|}{ Inflation } & \multicolumn{3}{|c|}{ GDP } \\
\hline & Average & SD & $\mathrm{CV}$ & Average & SD & $\mathrm{CV}$ & Average & SD & $\mathrm{CV}$ & Average & SD & $\mathrm{CV}$ \\
\hline \multicolumn{13}{|l|}{$\begin{array}{l}\text { Latin American } \\
\text { countries }\end{array}$} \\
\hline Argentina & 663.56 & 950.55 & 1.43 & 0.82 & 6.18 & 7.56 & 6.02 & 12.23 & 2.03 & 2.09 & 6.41 & 3.07 \\
\hline Uruguay & 65.86 & 26.06 & 0.40 & 1.35 & 5.24 & 3.88 & 26.39 & 21.32 & 0.81 & 1.29 & 5.48 & 4.24 \\
\hline Venezuela & 25.42 & 5.33 & 0.21 & 1.55 & 5.33 & 3.44 & 40.15 & 24.48 & 0.61 & -0.18 & 5.15 & -29.42 \\
\hline \multicolumn{13}{|l|}{$\begin{array}{l}\text { Other emerging } \\
\text { countries }\end{array}$} \\
\hline China* & 10.16 & 7.78 & 0.77 & 9.23 & 3.93 & 0.43 & 6.00 & 8.40 & 1.40 & 9.76 & 2.44 & 0.25 \\
\hline Egypt** & 18.19 & 3.27 & 0.18 & 5.14 & 2.26 & 0.44 & 6.69 & 4.71 & 0.70 & 4.62 & 1.37 & 0.30 \\
\hline India & 9.52 & 2.58 & 0.27 & 5.46 & 2.20 & 0.40 & 7.50 & 3.83 & 0.51 & 6.09 & 1.35 & 0.22 \\
\hline Malaysia & 3.63 & 2.78 & 0.77 & 6.44 & 3.35 & 0.52 & 2.96 & 1.33 & 0.45 & 6.02 & 5.61 & 0.93 \\
\hline Turkey & 53.23 & 23.15 & 0.43 & 4.26 & 3.61 & 0.85 & 68.81 & 22.02 & 0.32 & 3.52 & 5.81 & 1.65 \\
\hline Russia & n.a. & n.a. & n.a. & n.a. & n.a. & n.a. & 147.94 & 258.80 & 1.75 & 0.04 & 7.33 & 201.68 \\
\hline South Africa*** & 14.64 & 1.96 & 0.13 & 1.92 & 3.03 & 1.58 & 7.94 & 2.47 & 0.31 & 2.23 & 1.70 & 0.76 \\
\hline
\end{tabular}

$\mathrm{SD}=$ Standard deviation; $\mathrm{CV}=$ coefficient of variation (SD/Average)

Source: IMF $(2002,2004)$ / Deutsche Bank Research (www.dbresearch.de) for data on Russia.

Note: $\left({ }^{*}\right)$ Data for inflation: 1987-1991 and 1992-2003; $\left(^{* *}\right)$ Data for inflation and GDP: 1983-1991 and 1992-2003;

$\left.{ }^{* \star *}\right)$ Data for inflation and GDP: 1980-1991 and 1992-2001.

Table 4. Emerging IT countries (full period)

\begin{tabular}{|c|c|c|c|c|c|c|c|c|c|c|c|c|}
\hline \multirow{3}{*}{ Country } & \multicolumn{6}{|c|}{$1980-1991$} & \multicolumn{6}{|c|}{ 1992-2003 } \\
\hline & \multicolumn{3}{|c|}{ Inflation } & \multicolumn{3}{|c|}{ GDP } & \multicolumn{3}{|c|}{ Inflation } & \multicolumn{3}{|c|}{ GDP } \\
\hline & Average & SD & $\mathrm{CV}$ & Average & SD & $\mathrm{CV}$ & Average & SD & $\mathrm{CV}$ & Average & SD & $\mathrm{CV}$ \\
\hline \multicolumn{13}{|l|}{$\begin{array}{l}\text { Latin American } \\
\text { countries }\end{array}$} \\
\hline Brazil & 534.25 & 645.22 & 1.21 & 2.76 & 4.30 & 1.56 & 383.00 & 766.89 & 2.00 & 2.46 & 2.09 & 0.85 \\
\hline Chile & 21.78 & 6.82 & 0.31 & 5.06 & 3.00 & 0.59 & 6.86 & 4.28 & 0.62 & 5.44 & 3.64 & 0.67 \\
\hline Colombia & 25.33 & 6.17 & 0.24 & 3.37 & 1.49 & 0.44 & 15.49 & 8.10 & 0.52 & 2.98 & 2.00 & 0.67 \\
\hline Mexico & 61.65 & 39.07 & 0.63 & 2.64 & 3.84 & 1.45 & 15.02 & 10.52 & 0.70 & 2.72 & 3.61 & 1.33 \\
\hline \multicolumn{13}{|l|}{$\begin{array}{l}\text { Other emerging } \\
\text { countries }\end{array}$} \\
\hline Israel & 111.07 & 118.71 & 1.07 & 3.68 & 1.74 & 0.47 & 7.07 & 4.43 & 0.63 & 3.86 & 2.99 & 0.77 \\
\hline Poland* & 104.85 & 164.25 & 1.57 & -0.56 & 6.53 & 11.59 & 17.98 & 14.71 & 0.82 & 5.21 & 3.83 & 0.74 \\
\hline Czech Republic ${ }^{\star *}$ & 6.89 & 16.25 & 2.36 & n.a. & n.a. & n.a. & 7.61 & 5.61 & 0.74 & 2.24 & 2.18 & 0.97 \\
\hline Thailand & 5.82 & 5.33 & 0.92 & 7.70 & 3.12 & 0.41 & 3.65 & 2.47 & 0.68 & 4.33 & 5.61 & 1.30 \\
\hline South Korea & 8.49 & 8.24 & 0.97 & 7.82 & 3.62 & 0.46 & 4.34 & 1.87 & 0.43 & 5.40 & 4.39 & 0.81 \\
\hline
\end{tabular}


Figure 1 Brazil: average Selic rate from 1999 to 2005

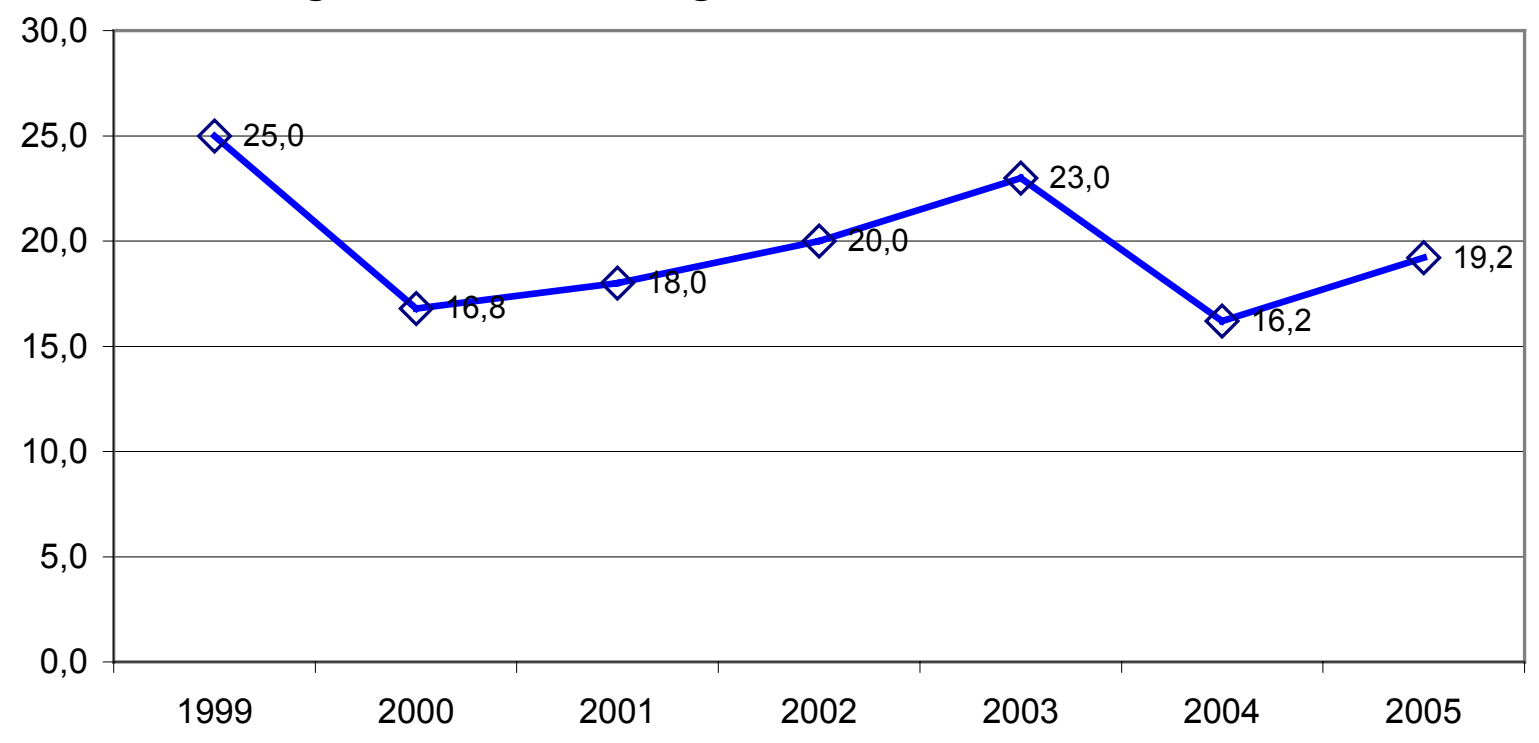

Source: Central Bank of Brazil (2006), www.bcb.gov.br (data obtained in May).

Note: Selic rate is the Central Bank of Brazil's basic interest rate and serves as a reference for the other rates of interest.

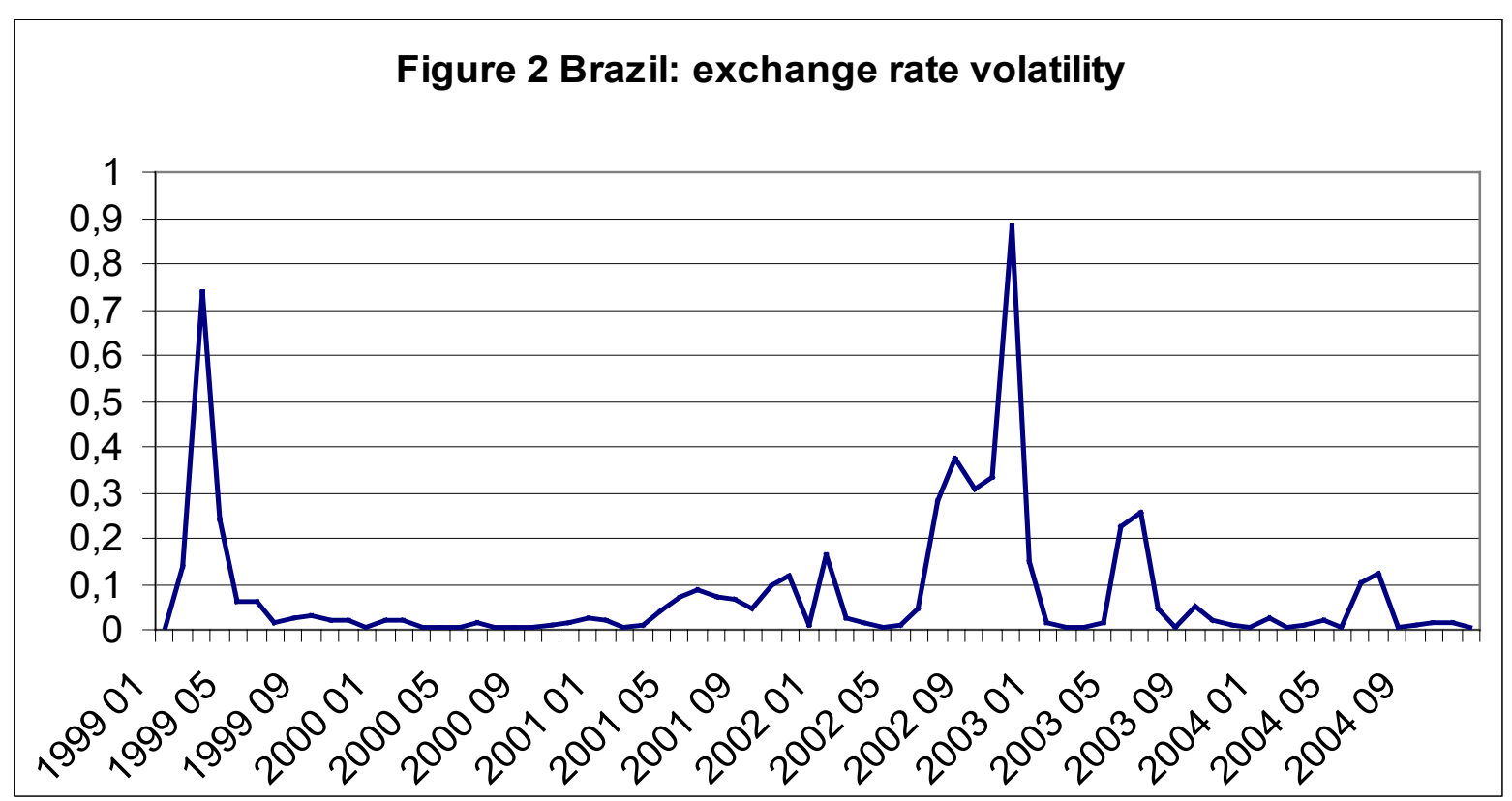

Source: Authors' calculations based on data from the Central Bank of Brazil (2006), www.bcb.gov.br (data obtained in May).

Note: Exchange rate volatility is calculated using a GARCH (Generalised Autoregressive Conditional Heteroskedastic) model, a non-linear model that is used to calculate the volatility of time series. 


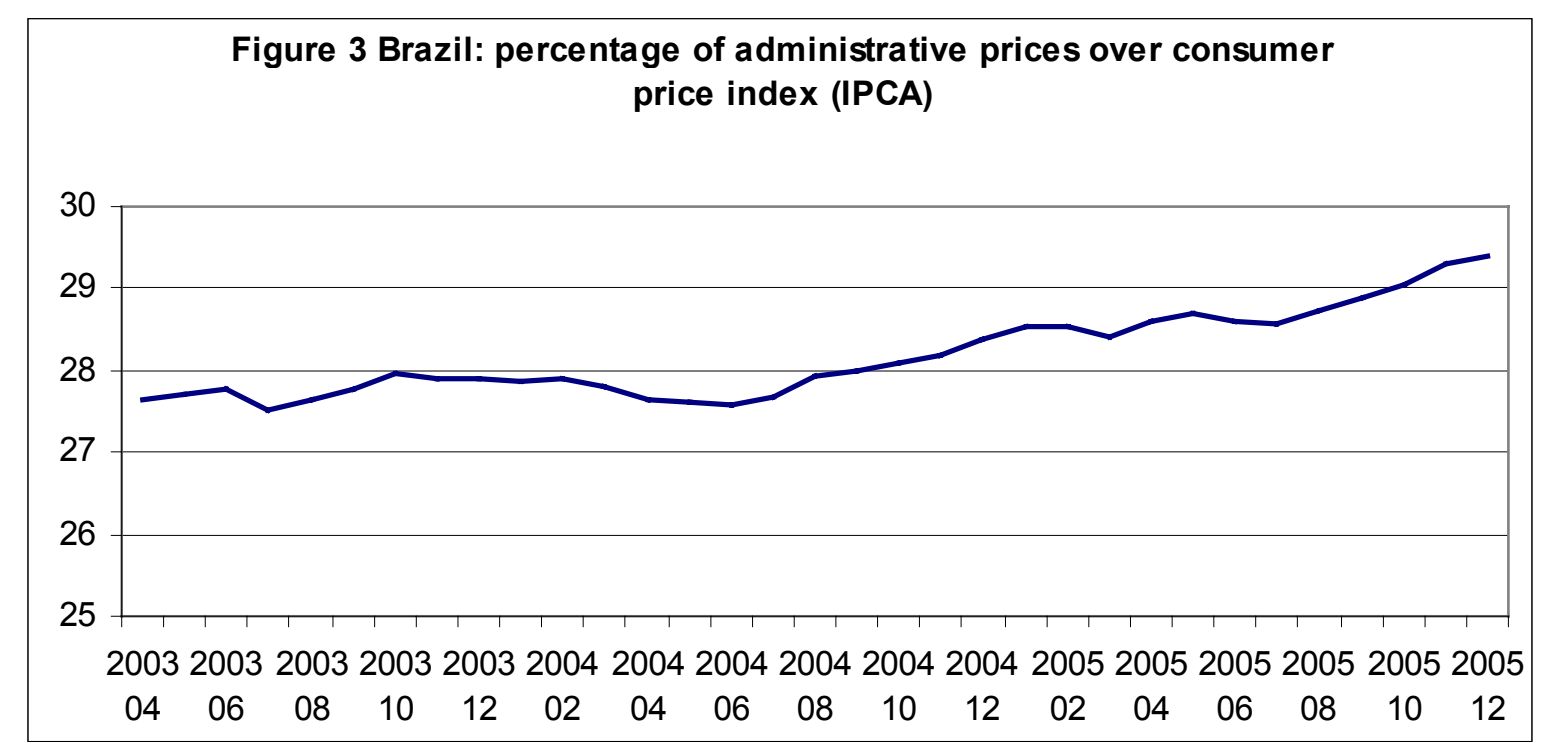

Source: Authors' calculations based on data from IBGE (www.ibge.gov.br).

Note: Administered prices include: utilities services (fixed telephone fees, residential electricity etc.), oil byproducts, private health plans, that are, prices that are or determined (or authorized) directly by government (oil, private health plans) or are governmental permission that include some sort of price indexation. See footnote 7 for details on IPCA.

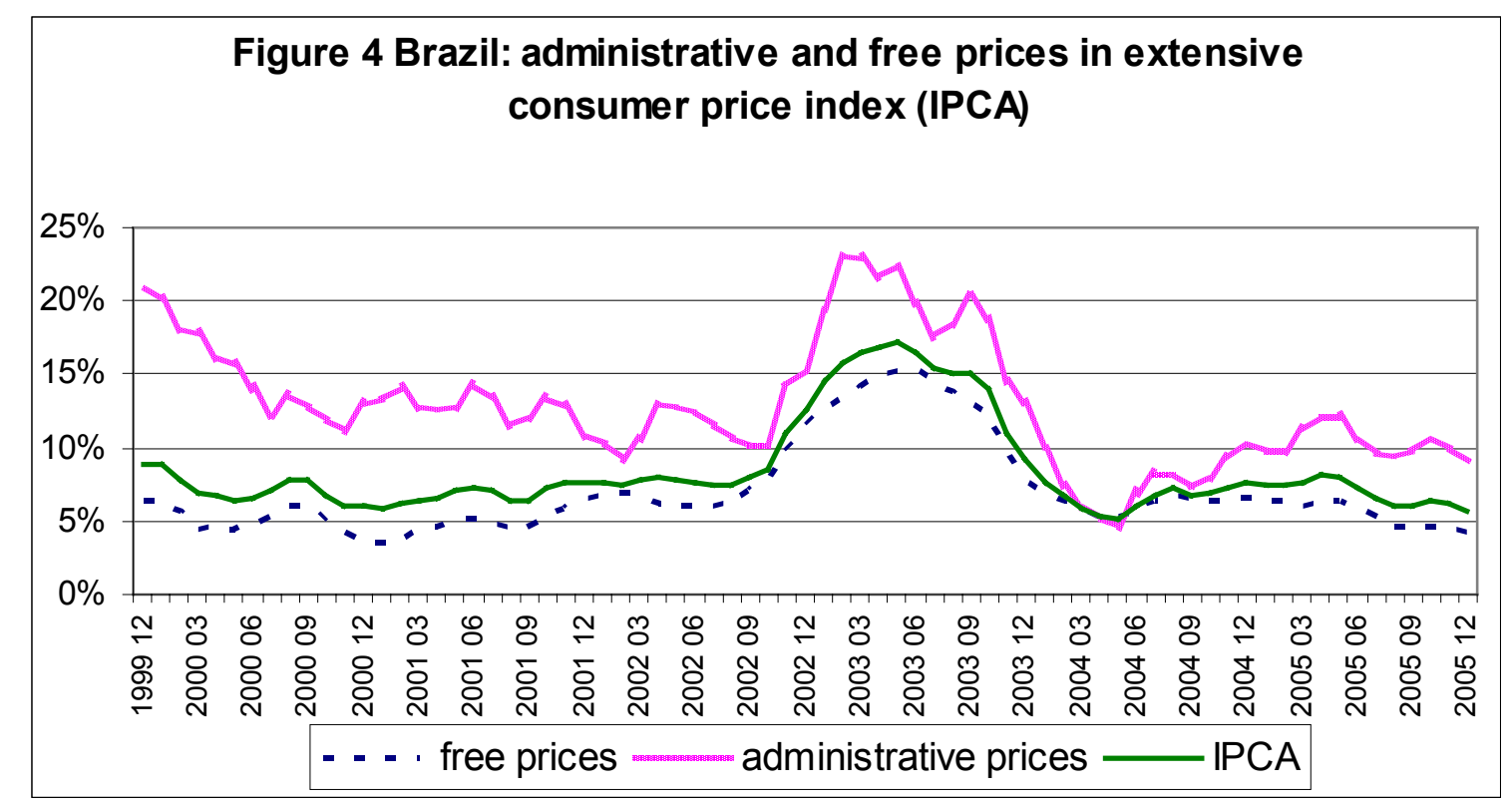

Source: IPEADATA (www.ipeadata.gov.br).

Note: For the definition of administered prices see note in Figure 3. 


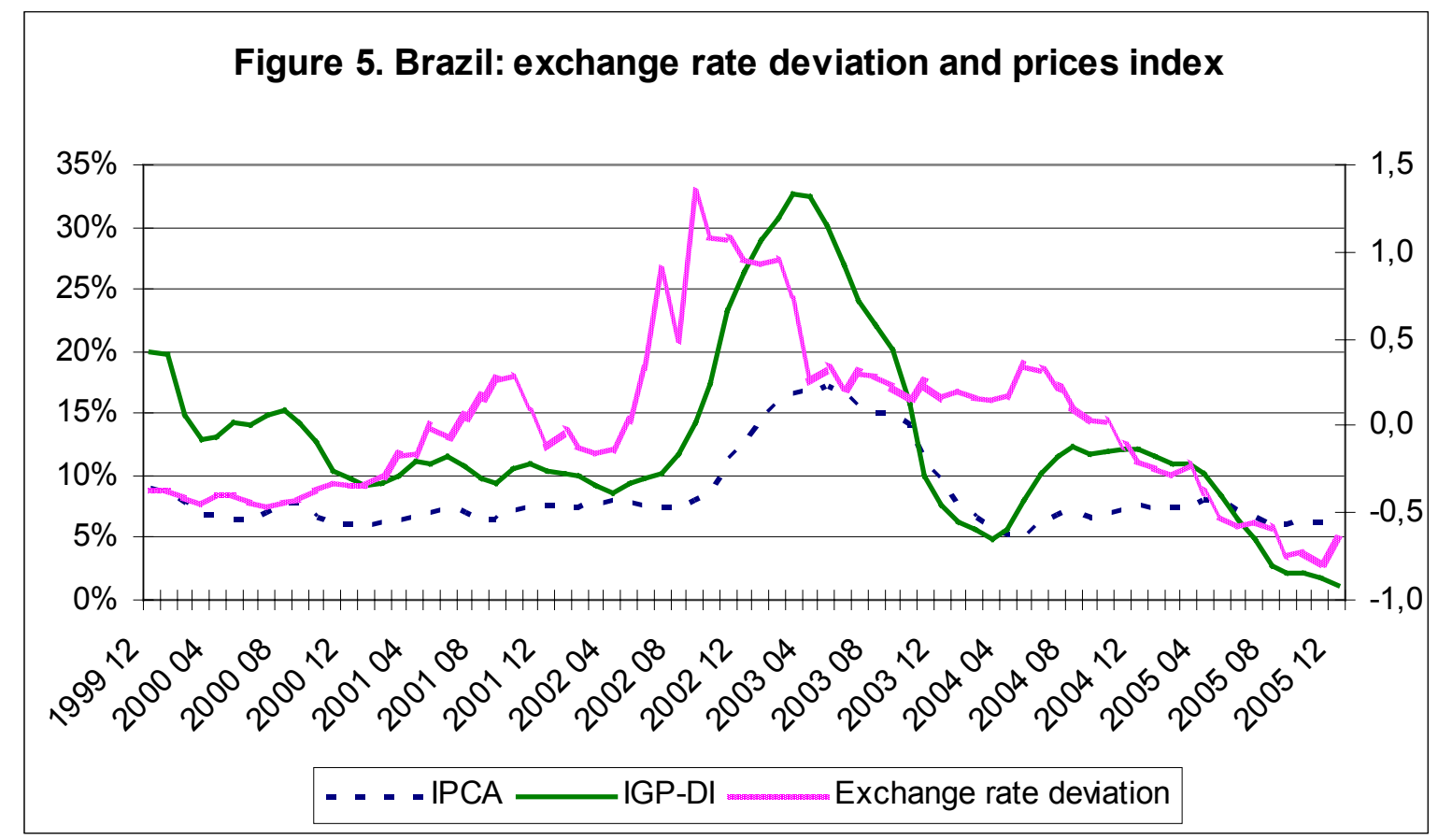

Source: IPEADATA (www.ipeadata.gov.br).

Note: see footnote 7 for details on IPCA, and footnote 19 for relevant details on IGP. Exchange rate deviation was calculated as the difference between the nominal exchange rate and its linear trend. 